\title{
Geomorphic surveying of submerged sea notches in Otranto area during the Quaternary, Ionian Sea coast, South Italy
}

\author{
Nourhan Nour \\ Nourhannour3@yahoo.com \\ PHD student, Physical Geography, Faculty of Arts, \\ Damietta University

\section{Magdy Toral} \\ Torab.magdy@gmail.com \\ Professor of Physical Geography, Faculty of Arts, \\ Damanhour University, Egypt

\section{Ilorahim Badawy} \\ Prof_ibadawi@du.edu.eg \\ Professor of Physical Geography, Faculty of Arts, \\ Damietta University, Egypt

\section{Giusepje Mastronuzz} \\ Gimastronuzzi@libero.it \\ Professor of Geology, Geophysics \& Geomorphology, \\ Bari University, Italy
}

Received on 11/10/2019

Accepted on 19/2/2020 


\section{GEOMORPHIC SURVEYING OF SUBMEREED SEA NOTCHES IN OTRANTO AREA DURING THE QUATERNARY, IONIAN SEA COAST, SOUTH ITALY}

\section{Nourhan Nour 1 - Magdy Toraln 2 \\ Ibrahim Badawy 3 - Giuseppe Mastronuzzi ${ }^{4}$}

\section{Abstract:}

Submerged notches that indicate negative sea level change evidence during The Quaternary. Through their study, the effects of sea level change and effect of tectonic lifting movements on them during the Quaternary are identified.

Submerged notches as negative evidence below MSL are studied in the field work in two areas: The first one is "San Foca" area that comprises three parts from north to south:" Torre di Roca Vecchia bay" and "Madonna di Roca Vecchia bay", the second area is "Castro", only "Porto Castro" is studied below the current sea level.

The studied area located in the Ionian Sea coast, South Italy, its total length is about $53 \mathrm{~km}$. The studied area is the south-east part of the Apulia region (southern Italy), stretching between the Ionian Sea and Adriatic Sea. It is located on the east coast of the Salento peninsula. Its coordinates are $40^{\circ} 0^{\prime} 2.43^{\prime \prime}$ to $40^{\circ} 18^{\prime} 6.85^{\prime \prime} \mathrm{N}$, and $18^{\circ} 16^{\prime}$ $10.10^{\prime \prime}$ to $18^{\circ} 31^{\prime} 30.99^{\prime \prime} \mathrm{E}$

The aims of this paper to define the effects of the Quaternary Sea level change on submerged notches, and study the evolution of coastal karst in current climate conditions. The methodology of this study depended upon extensive field and measurements of submerged notches, an in addition to GPS.

Key words: Submerged notches, Negative Sea Level Change Evidence, Otranto area, Ionian Sea coast, South Italy.

\section{Introduction:}

Submerged notches that indicate negative sea level change evidence during the Quaternary. Through their study, the effects of sea level change and effect of tectonic lifting movements on them during the Quaternary are identified.

Submerged notches as negative evidence below MSL are studied in the field work in two areas: The first one is "San Foca" area that comprises three parts from north to south:" Torre di Roca Vecchia bay" and "Madonna di Roca Vecchia bay", the second area is "Castro", only "Porto Castro" is studied under evidence from modern sea level.

\section{The study area:}

The area under study is "Otranto" area, Ionian Sea coast, South Italy. Its total length is about $53 \mathrm{~km}$. The studied area is the south-east part of the Apulia region (southern Italy), stretching between the Ionian Sea and Adriatic Sea. It is located on the east coast of the Salento peninsula. Its coordinates are $40^{\circ} 0^{\prime} 2.43^{\prime \prime}$ to $40^{\circ} 18^{\prime} 6.85^{\prime \prime}$ $\mathrm{N}$, and $18^{\circ} 16^{\prime} 10.10^{\prime \prime}$ to $18^{\circ} 31^{\prime} 30.99^{\prime \prime} \mathrm{E}$, (Fig.1).

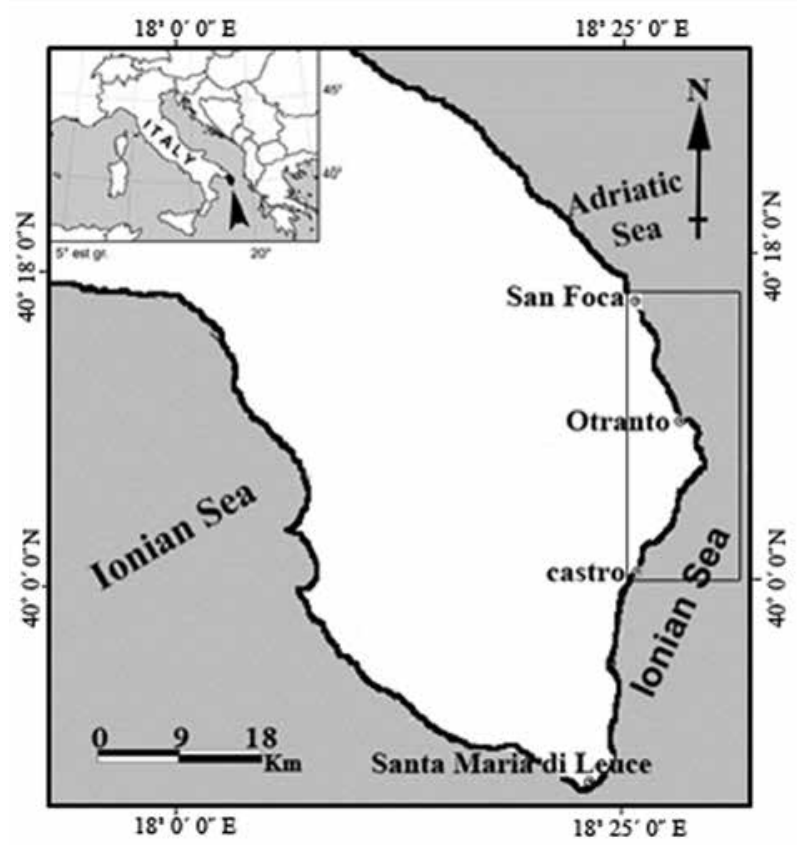

(Fig.1) Location of the study area

${ }^{1}$ PHD student, Physical Geography, Faculty of Arts, Damietta University, nourhannour3@yahoo.com

2 Professor of Physical Geography, Faculty of Arts, Damanhour University, Egypt Torab.magdy@gmail.com

3 Professor of Physical Geography, Faculty of Arts, Damietta University, Egypt, Prof_ibadawi@du.edu.eg

${ }^{4}$ Professor of Geology, Geophysics \& Geomorphology,Bari University, Italy, gimastronuzzi@libero.it 


\section{Objectives:}

a. To define the effects of the Quaternary Sea level change on submerged notches.

b. To study the evolution of coastal karst in current climate conditions.

\section{Data and methods:}

The geomorphological approach encapsulates the following techniques:

\section{A- Topographic maps:}

Scale 1: 25000 produced by the Italian Survey in 1960, 2 plates.

B- Geological maps:

Scale 1: 10000 produced by the Italian Survey in 1960, 2 plates.

C- Meteorological data published on "Otranto" Station, It is located in the middle of the study area, at a level of 28 meters and meteorological study within (1982-2014).

D- Field surveying:

The authors visited the study area twice during 2015 and 2016. They studied "Castro" and "San Foca" areas for three weeks in September 2015. E- ARC GIS Analysis:

- By using ARC GIS.10.4.1 analysis is utilized to investigate the geological, topographic maps and satellite image to study the morphological and geomorphology of the study area.

\section{4- Geology of study area:}

The study area belongs to the Salento Peninsula which is characterized by a geological diversity where the formations of the tertiary period and Quaternary are. Therefore, late Cretaceous, limestone and breccia formations as well as sandstone formations (Calcarenite) spread along their east coast.

The ancient geographical map of the formations of the Salento Peninsula shows that the peninsula consists of a series of the Miocene era formations which are above the Cretaceous and Paleogene era formations as a result of the geological development of different parts of the region.
It also shows that the Miocene formations are incompatible and stratified below Cretaceous and Paleogene formations, but they are characterized by conformity with the Paleocene and Pleistocene formations, (Fig.2).

During the Miocene, the Salento Peninsula was characterized by dominant carbon sediments, and these are divided into two parts: "Pietra Leccese Formations" (Giovene, 1810) and "Andrano Calcarenite Formations" (Martins, 1967).

Based on the geological map of the study area which extends from San Foca in the north to Castro in the south, the area has the following characteristics (Fig.2):

\section{1- Cretaceous formations:}

Cretaceous formations are the oldest geological formations in the study area, and they appear at the mouth of the valley of "Santa Cesare".

\section{2- Tertiary period formations:}

The tertiary period formations, the main formations of the geology of the region, are concentrated in the northern part of the study area. Most of them are covered in the southern part by modern sediments, although they appear in some places, especially in estuaries such as Santa Cesarea.

The formations of sandstone (Calcarenite), which date back to the late Paleocene era, are among the most important geological formations in addition to the formations of the Cretaceous limestone stones which go back to the Cretaceous and Oligocene era.

\section{The Quaternary formations:}

The Quaternary formations are scattered along the coastline. They date back to different times: middle and late Pleistocene (Calcarenite formations) and during the Holocene (limestone and breccia).

Faults take a general direction to the northeast/ south-west and sometimes take a north-northeast 
/ south-west direction, which cuts off some of the sedimentary Formation of the late Pleistocene period along the coastline (Martinis, 1967; Bosellini et al., 1999). These faults are formed in submerged parts of the Apulia peninsula edge. Incidentally, the seismic activity that was active in the last period of the Pleistocene until the present appears on the bottoms of the Otranto region where the tectonic plates migrate about 200-300 meters (Merlini et al. , 2000), (Fig.3).

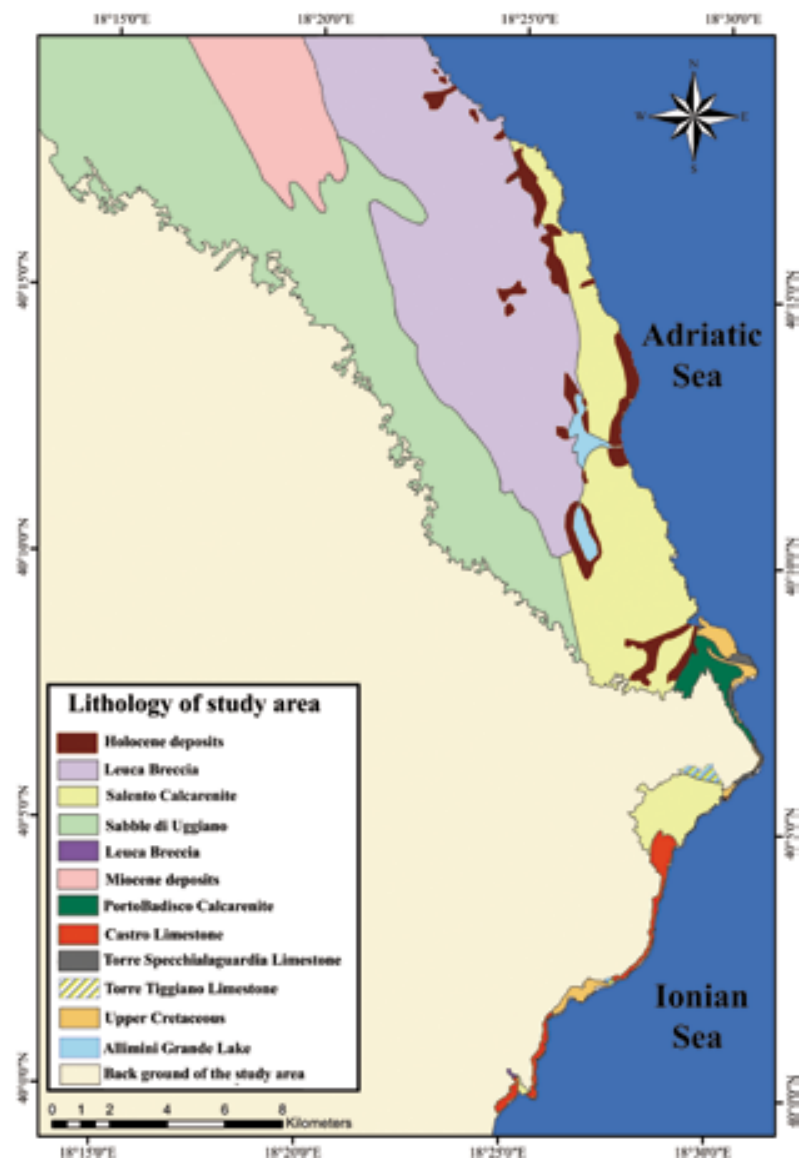

(Fig.2) Geology of the study area

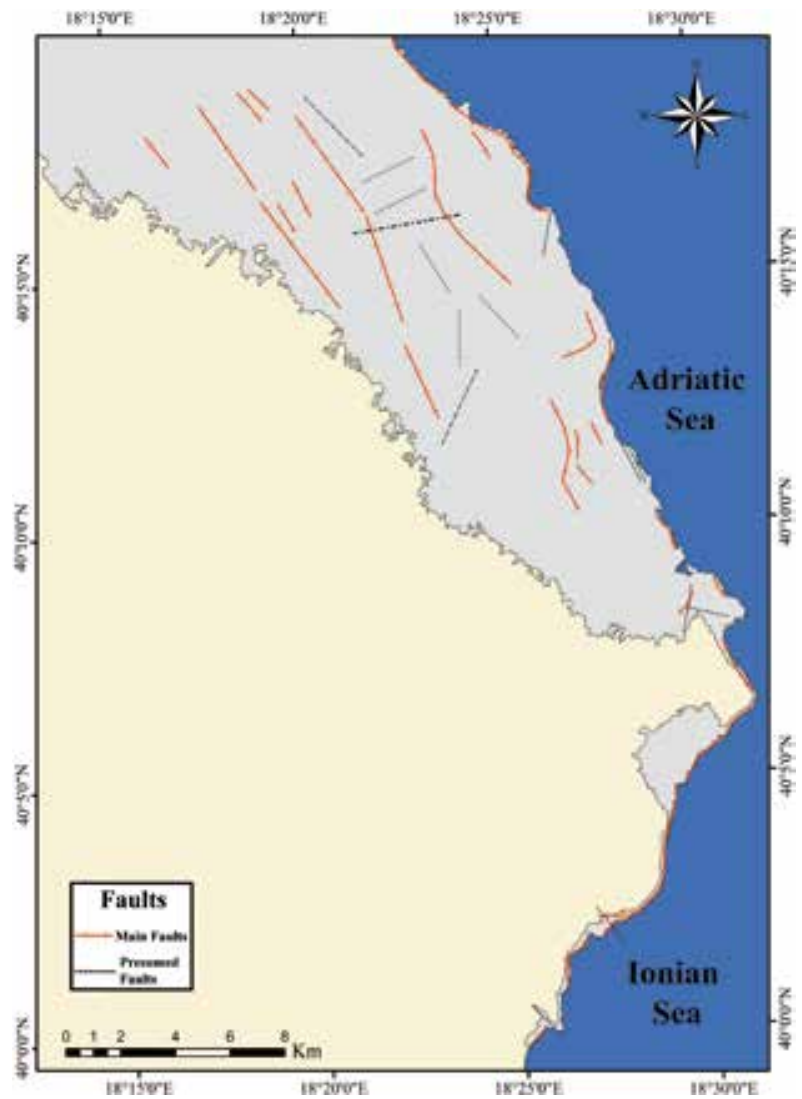

(Fig.3) Lithology of the study area

\section{5- Climate Data:}

\section{5-1- Temperature:}

The results of the statistical analysis of temperature show that the relationship between temperature and solution rates is positive. The highest temperature in the study area is temperature range is about $16.6^{\circ}$, maximum temperature about $19.9^{\circ}$, but minimum temperature is about $13.4^{\circ}$.

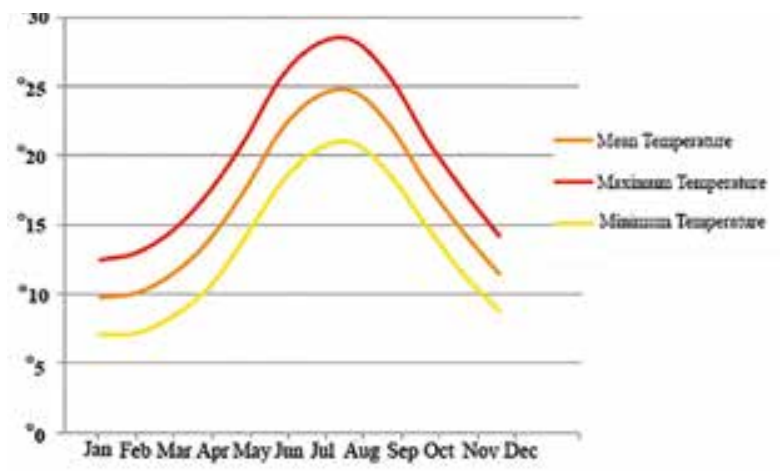

(Fig.4) Temperature in Otranto meteorological Station 


\section{5-2- Humidity:}

The Maximum Average of humidity rate is about $79.7 \%$, while the minimum average is $74.7 \%$

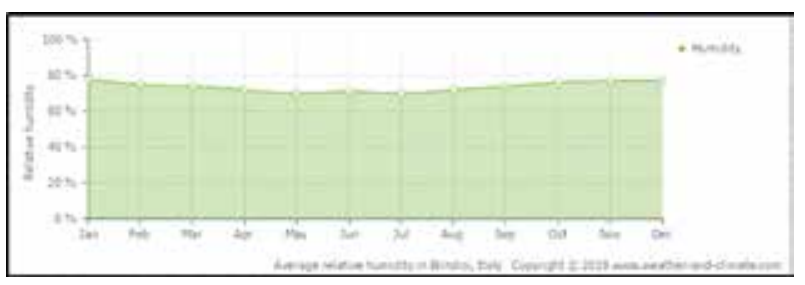

(Fig. 5) Humidity in Otranto meteorological Station

\section{5-3- Precipitation:}

The amount of precipitation is a major factor that affects solution rates. The maximum amount of rainfall is $709 \mathrm{~mm}$.

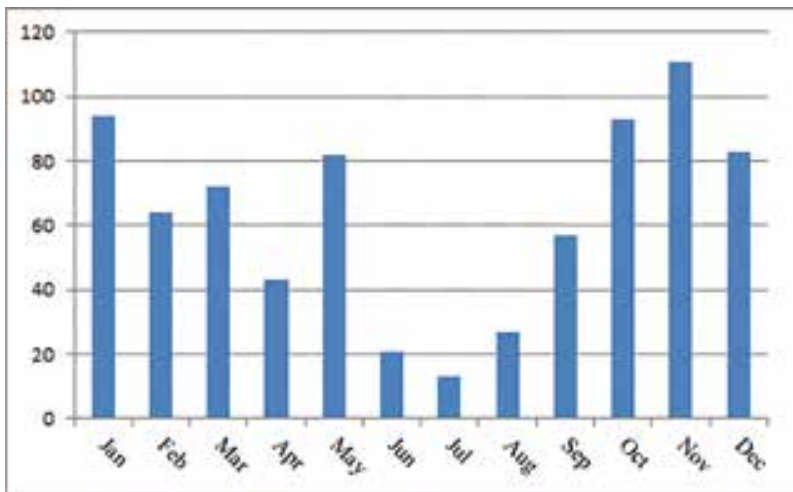

(Fig.6) Precipitation Amount in Otranto meteorological Station

\section{5-4- Wind:}

The dominant direction of the wind in Otranto Station is NNW and SSE wind.

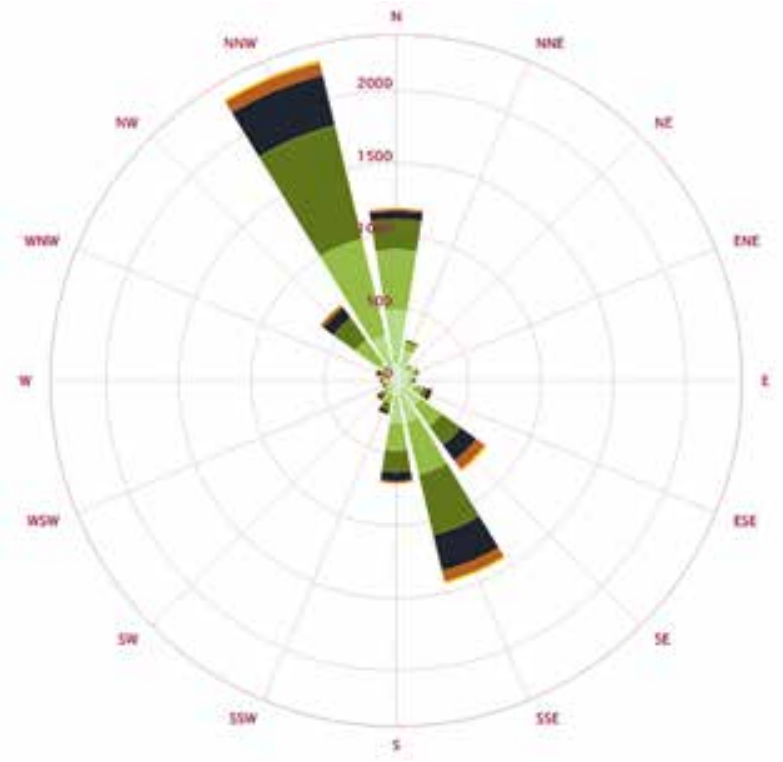

(Fig.7) Wind rose directions in Otranto meteorological Station

\section{Results and discussion:}

\subsection{The morphological characteristics of} submerged notches:

This article studies the morphological characteristics of submerged notches in the study area and measures the following dimensions in the field, (Fig.8):

a) Inward depth of vertex.

b) Wide.

c) Roof height from sea level.

d) Floor height from sea level.

e) Vertex height from sea level.

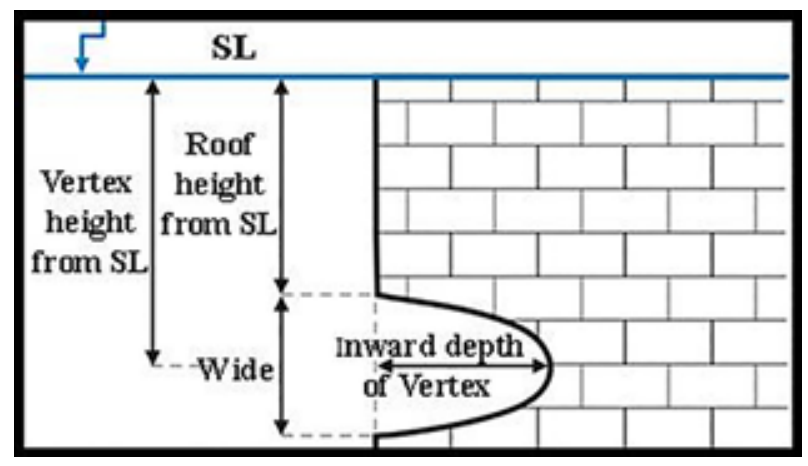

(Fig.8) Dimensions of submerged notches in the field work, (After: Torab, 2016) 
In the study area, Notches are classified by shape. Some of them take a "U" shape, which indicates the inward depth of the entrance is and affected by marine erosion of hydraulic waves. On the other hand, others take a "V" shape where the depth of the entrance is affected by joints and applied to the following areas:

\section{I-San Foca Area:}

In "San Foca" area, two parts are examined: "Torre di Roca Vecchia Bay" and "Madonna di Roca Vecchia Bay".

\section{I-A- Torre di Roca Vecchia Bay:}

Table (1) shows the dimensions of negative notches in the area of "Torre di Roca Vecchia Bay". There two types of submerged notches: U-shaped and V-shaped. The inward depth of the vertex of the former is about $40 \mathrm{~cm}$, and the width of the entrance is about $80 \mathrm{~cm}$. On the other hand, in the latter, the inward depth of the vertex is about $120 \mathrm{~cm}$, and the width of the entrance is about $90 \mathrm{~cm}$, (Fig.9, 10).

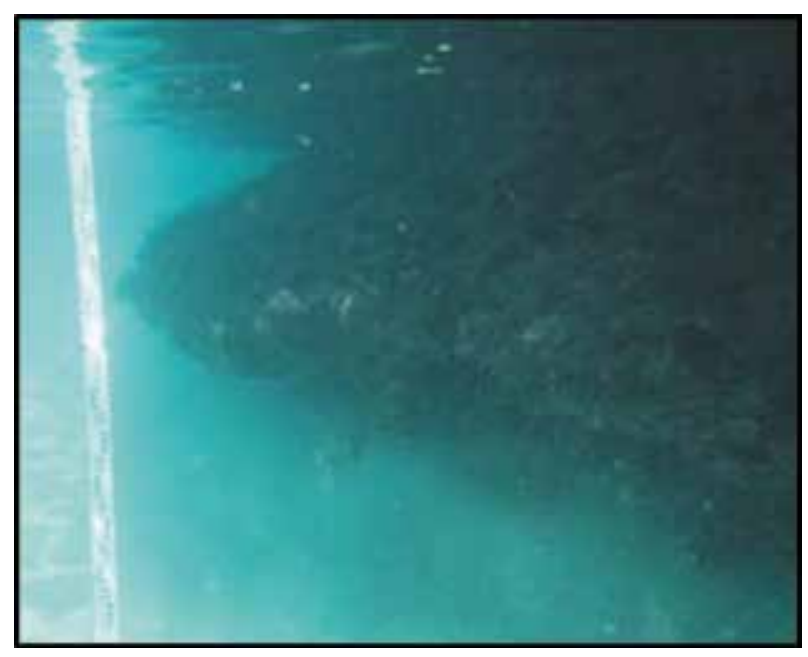

(Fig.10) Type of V-shaped notches in "Torre di Roca Vecchia Bay'

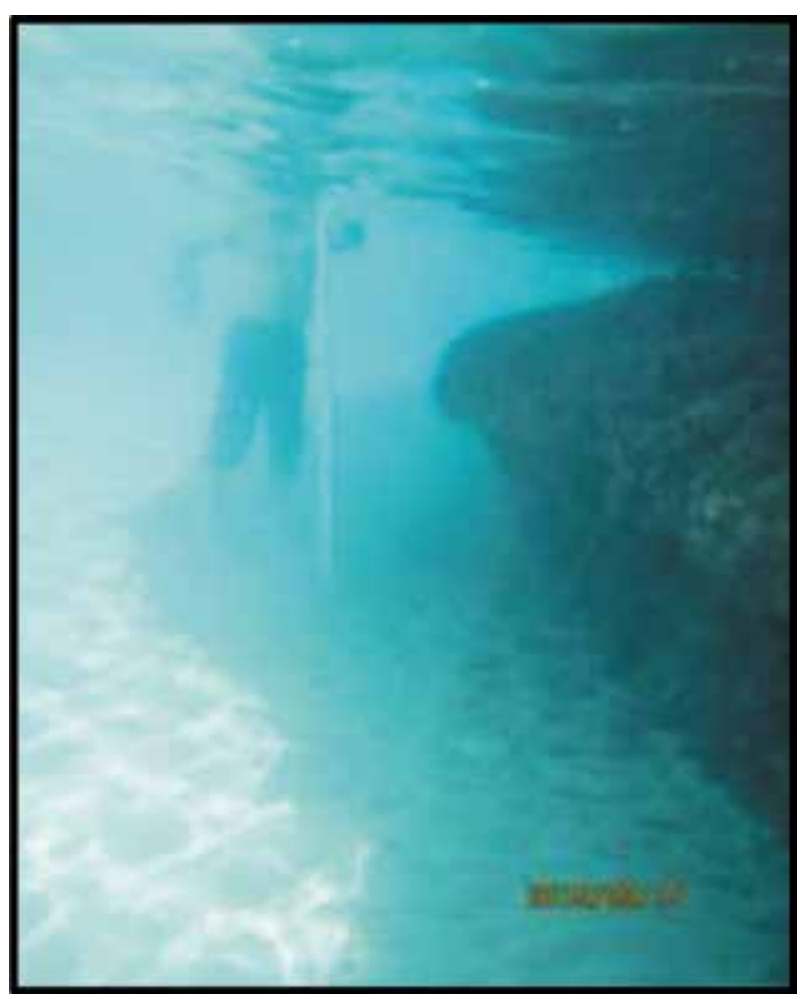

(Fig.10) Type of V-shaped notches in "Torre di Roca Vecchia Bay'

xTable (2) and Fig (11) show the correlation between some variables that indicate the effects of sea level change, and it is noted from the study of 2 variables to measure the characteristics of notches in "Torre di Roca Vecchia Bay" that there are a positive relationship between the inward depth of vertex, the width of the entrance and the vertex height from sea level. Likewise, the inward depth of the vertex and the height of the roof of notches from MSL are negatively related. Therefore, effects caused by the vertical and horizontal joints and the hydraulic action of waves during the Quaternary are produced.

Table (1) the Dimensions of sea notches in "Torre di Roca Vecchia Bay"

\begin{tabular}{|c|c|c|c|c|c|}
\hline No. & $\begin{array}{c}\text { Inward depth of } \\
\text { vertex }(\mathrm{cm})\end{array}$ & $\begin{array}{c}\text { Width of the } \\
\text { entrance }(\mathrm{cm})\end{array}$ & $\begin{array}{c}\text { Roof height } \\
\text { from MSL }(\mathrm{cm})\end{array}$ & $\begin{array}{c}\text { Vertex height } \\
\text { from MSL }(\mathrm{cm})\end{array}$ & $\begin{array}{c}\text { Types of notch } \\
\text { shape }\end{array}$ \\
\hline 1 & 40 & 80 & 80 & 100 & $\mathrm{U}$ \\
\hline 2 & 120 & 90 & 60 & 120 & $\mathrm{~V}$ \\
\hline
\end{tabular}


Table (2) and Fig (11) show the correlation between some variables that indicate the effects of sea level change in "Torre di Roca Vecchia Bay"

\begin{tabular}{|c|c|c|c|}
\hline First variable & Second variable & Correlation & $\begin{array}{c}\text { Number of } \\
\text { variables }\end{array}$ \\
\hline $\begin{array}{c}\text { Inward depth of } \\
\text { vertex }\end{array}$ & $\begin{array}{c}\text { Width of the } \\
\text { entrance }\end{array}$ & 1 & 2 \\
\hline $\begin{array}{c}\text { Inward depth of } \\
\text { vertex }\end{array}$ & Roof height & -1 & 2 \\
\cline { 1 - 2 } $\begin{array}{c}\text { Inward depth of } \\
\text { vertex }\end{array}$ & $\begin{array}{c}\text { Vertex height from } \\
\text { MSL }\end{array}$ & 1 & \\
\hline
\end{tabular}

\section{I-B-Madonna di Roca Vecchia Bay:}

Table (3) shows the dimensions of negative notches in the area of "Madonna di Roca Vecchia Bay". Besides, the U-shaped notches are more common as a result of hydraulic action of waves, so the maximum inward depth of vertex is about $100 \mathrm{~cm}$, and the width of the entrance is about $110 \mathrm{~cm}$, (Fig.12, 13).

Table (3) the Dimensions of sea notches in "Madonna di Roca Vecchia Bay"

\begin{tabular}{|c|c|c|c|c|c|}
\hline No. & $\begin{array}{c}\text { Inward depth of } \\
\text { vertex } \mathbf{( c m )}\end{array}$ & $\begin{array}{c}\text { Width of the } \\
\text { Entrance (cm) }\end{array}$ & $\begin{array}{c}\text { Roof Height } \\
\text { from MSL (cm) }\end{array}$ & $\begin{array}{c}\text { Vertex Height } \\
\text { from MSL (cm) }\end{array}$ & $\begin{array}{c}\text { Types of notch } \\
\text { shapes }\end{array}$ \\
\hline 1 & 40 & 30 & 40 & 65 & $\mathrm{U}$ \\
\hline 2 & 100 & 100 & 0 & 50 & $\mathrm{U}$ \\
\hline 3 & 80 & 110 & 0 & 60 & $\mathrm{U}$ \\
\hline
\end{tabular}

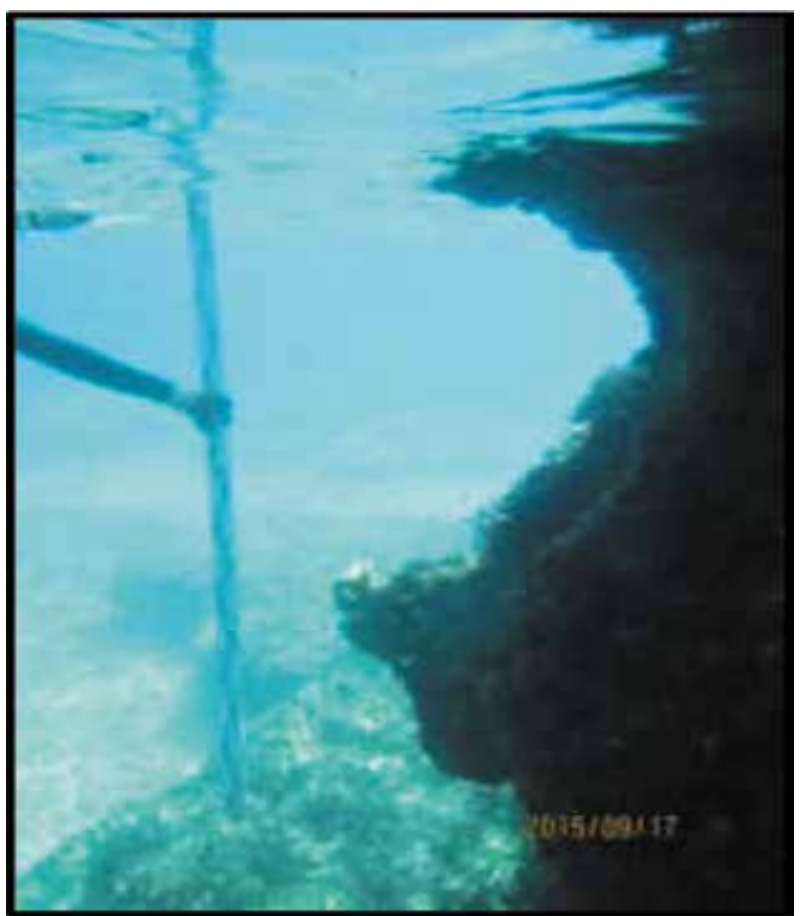

(Fig. 12) Type of U-shaped notches in "Madonna di Roca Vecchia Bay "

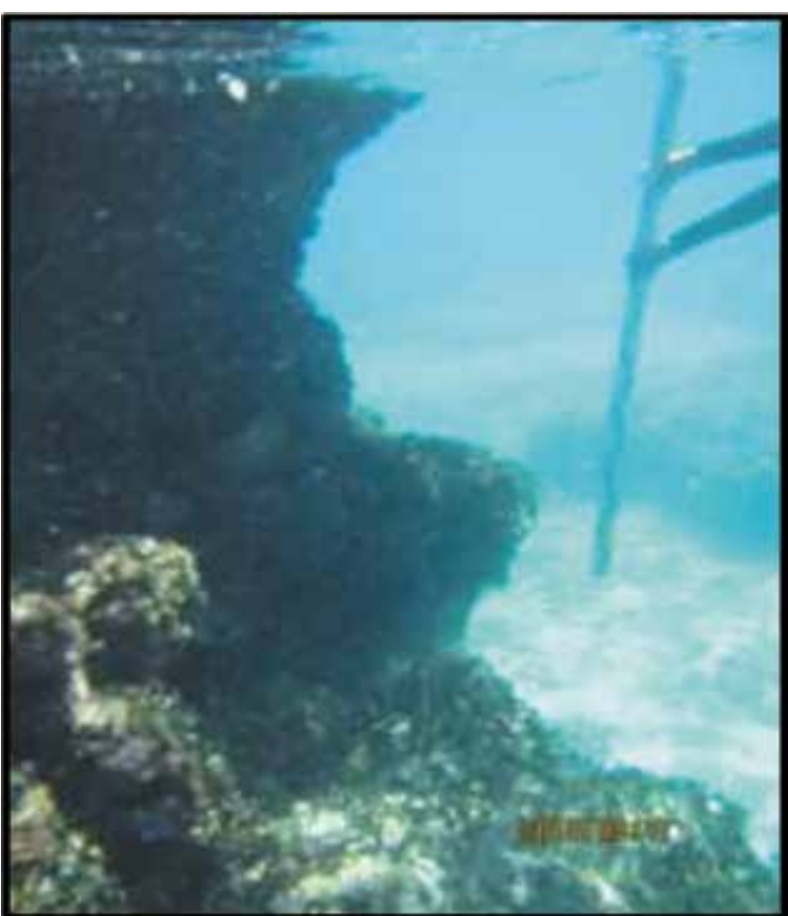

(Fig.13) Type of V-shaped notches in "Madonna di Roca Vecchia Bay" 
Table (4) and Fig (14) show the correlation between some variables that indicate the effects of sea level change, and it is noted from the study of 3 variables to measure the characteristics of notches in "Madonna di Roca Vecchia Bay" that there are a positive relationship between the inward depth of the vertex and the width of the entrance. Analogously, the inward depth of the vertex, the height of the roof of the notches from MSL and the vertex height from sea level are negatively related. Thus, effects caused by the hydraulic action of waves during the Quaternary are produced.

\section{II- Castro Area:}

In "Castro" area, only "Porto Castro" is studied under evidence from modern sea level:

II-A- Porto Castro:

Table (5) shows the dimensions of the negative notches in the area of "Porto Castro". It has two types of submerged notches: U-shaped, and V-shaped. The inward depth of the vertex of the former is about $60 \mathrm{~cm}$, and the width of the entrance is about $130 \mathrm{~cm}$. On the other hand, while in the latter, the inward depth of the vertex is about $80 \mathrm{~cm}$, and the width of the entrance is about $170 \mathrm{~cm}$, (Fig.15, 16).

Table (4) and Fig (14) show the correlation between some variables that indicate the effects of sea level change in "Madonna di Roca Vecchia Bay"

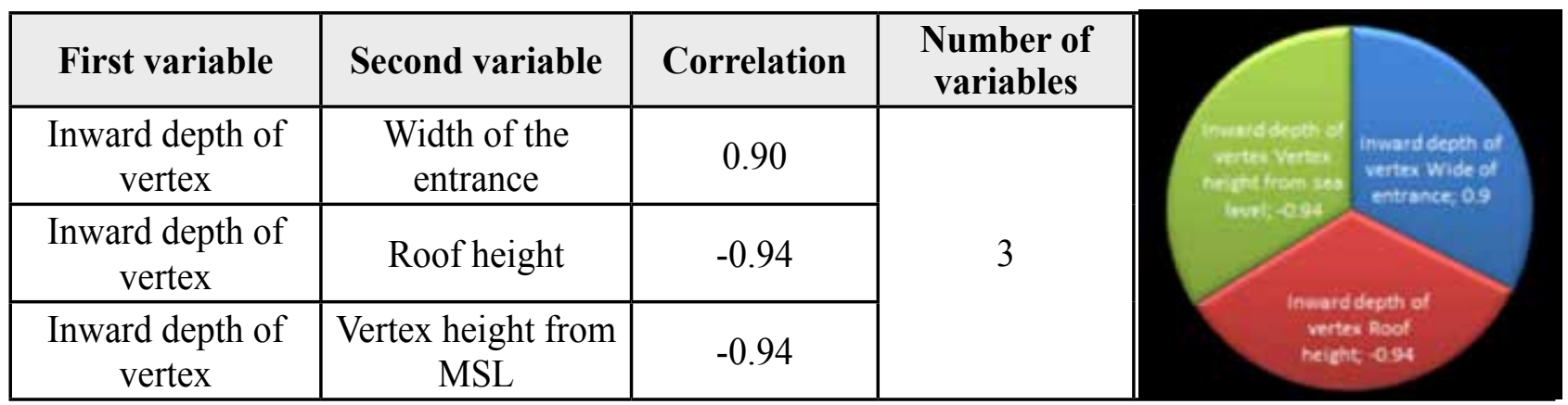

Table (5) the Dimensions of sea notches in "Porto Castro"

\begin{tabular}{|c|c|c|c|c|c|}
\hline No. & $\begin{array}{c}\text { Inward depth of } \\
\text { vertex } \mathbf{( c m )}\end{array}$ & $\begin{array}{c}\text { Width of the } \\
\text { entrance } \mathbf{( c m )}\end{array}$ & $\begin{array}{c}\text { Roof Height } \\
\text { from MSL (cm) }\end{array}$ & $\begin{array}{c}\text { Vertex Height } \\
\text { from MSL (cm) }\end{array}$ & $\begin{array}{c}\text { Types of notch } \\
\text { shapes }\end{array}$ \\
\hline 1 & 40 & 80 & 100 & 140 & $\mathrm{U}$ \\
\hline 2 & 60 & 130 & 160 & 260 & $\mathrm{U}$ \\
\hline 3 & 80 & 170 & 100 & 170 & $\mathrm{~V}$ \\
\hline
\end{tabular}

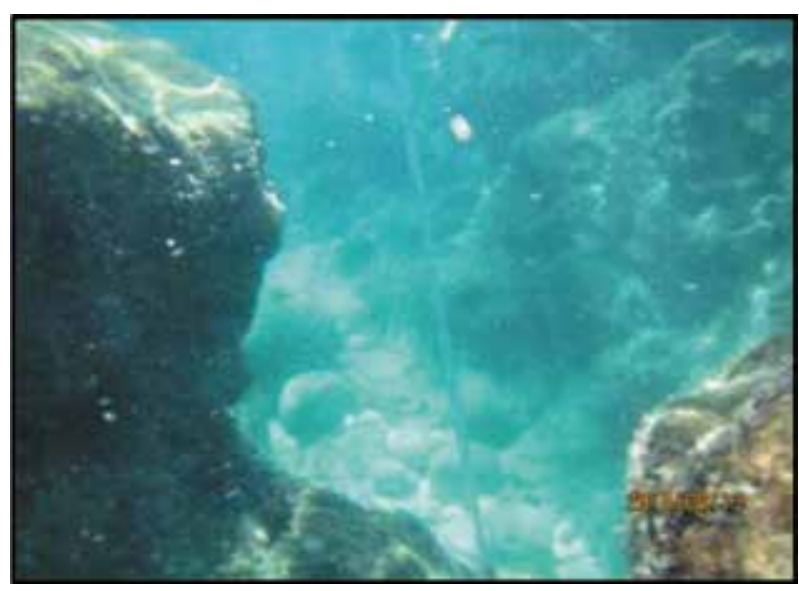

(Fig.15) Type of U-shaped Notches in "Porto Castro"

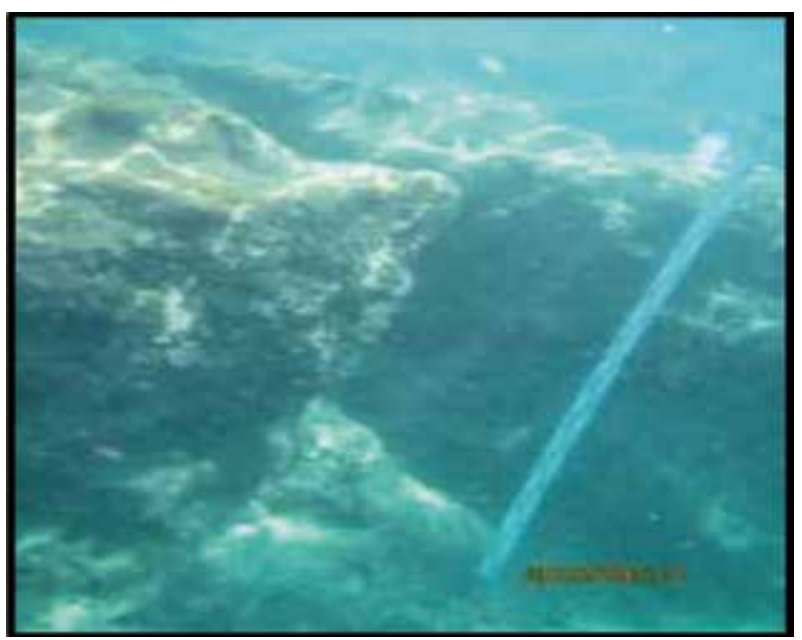

(Fig.16) Type of V-shaped Notches in " Porto Castro " 
Table (6) and Fig (17) show the correlation between some variables that indicate the effects of sea level change, and it is noted from the study of 3 variables to measure the characteristics of notches in "Porto Castro" that there is a positive relationship between the inward depth of the vertex and the width of the entrance. Similarly, the inward depth of vertex, the height of the roof of notches from MSL and the vertex height from sea level are positively related. Hence, effects caused by marine erosion during the Quaternary are produced.

Table (6) and Fig (17) show the correlation between some variables that indicate the effects of sea level change in "Porto Castro"

\begin{tabular}{|c|c|c|c|}
\hline First variable & Second variable & Correlation & $\begin{array}{c}\text { Number of } \\
\text { variables }\end{array}$ \\
\hline $\begin{array}{c}\text { Inward depth of } \\
\text { the vertex }\end{array}$ & $\begin{array}{c}\text { Width of the } \\
\text { entrance }\end{array}$ & 0.99 & \multirow{2}{*}{0.01} \\
\hline $\begin{array}{c}\text { Inward depth of } \\
\text { vertex }\end{array}$ & Roof height & 0.24 & \\
\hline $\begin{array}{c}\text { Inward depth of } \\
\text { vertex }\end{array}$ & $\begin{array}{c}\text { Vertex height from } \\
\text { MSL }\end{array}$ & \\
\hline
\end{tabular}

\section{6- Conclusion:}

Thestudyareaisinacontinuousgeomorphological development as a result of erosion and the impact of tectonic lifting movements during the Quaternary, submerged notches in San Foca area that are limited to $(0-(-2))$ m below the modern sea level, while submerged notches in Castro area at two levels of (0 - (-2), (- 2) - (-4) ) m below the modern sea level, indicating the effects of the tectonic lifting movements.

\section{7-References:}

1- Bosellini, A., Bosellini, A., Colalongo, M. L., Parente, M., Russo, A., Vescogni, A., 1999. Statigraphic architecture of the Salento Coast from Capo D' Otranto to S. Maria Di Leuca (Apulia, Southern Italy). Rivista Italiana di Paleontologia e Stratigrafia,v. 105, no.3, 397-416.

2- Martinis, B., 1967. Note geologiche sui dintorni di Casarano e Castro (Lecce). Rivista Italiana di Paleontologia e Stratigrafia 73, 1-63.

3- Merlini, S., Cantarella, G., Dogliosi, C., 2000. On the seismic profile Crop M5 in the Ionian Sea. Boll. Soc. Geol. Ital. 119, 227-236.

4- Torab ,M., 2016.Geomophological \& Geoarchaeological Indicators of the Holocene Sea-Level Changes on Ras El Hekma Area, NW Coast of Egypt. Journal of African Earth Sciences Volume 114, February, 85-95. 